\title{
PENGARUH INVENTARISASI ASET, PENGGUNAAN ASET, PENGAMANAN DAN PEMELIHARAAN ASET TERHADAP OPTIMALISASI ASET TETAP TANAH MELALUI PEMANFAATAN ASET PADA PEMERINTAH KABUPATEN MALANG
}

\author{
Arif Wicaksana ${ }^{1}$, Harmono ${ }^{2}$, Sari Yuniarti ${ }^{3 *}$ \\ 1)Magister Manajemen Program Pascasarjana \\ 2)Departemen Manajemen Fakultas Ekonomi dan Bisnis \\ 3)Departemen D-III Perbankan dan Keuangan Fakultas Ekonomi dan Bisnis \\ Universitas Merdeka Malang \\ *)Korespondensi: sari.yuniarti@unmer.ac.id
}

\begin{abstract}
In the era of national transformation and regional autonomy, there have been many breakthroughs in the management of land fixed assets, but many financial problems and land assets have not been implemented optimally, effectively and efficiently in their management. This study was used to analyze the effect of asset management on the optimization of fixed land assets in Malang Regency Government. The independent variables used in this study were asset inventory, asset use, asset security, and maintenance, while the dependent variable used asset utilization and asset optimization with a sample of 62 respondents. This type of research is quantitative using multiple regression analysis and path analysis method. The results showed that there was an indirect effect of asset inventory, asset use, and asset security and maintenance on asset optimization through asset utilization where security and asset maintenance had a significant and positive effect, while asset inventory and asset use had no effect on asset optimization. The direct effect of asset inventory, asset use, asset security, and maintenance on asset optimization shows that asset inventory and asset security have a significant and positive effect on asset optimization, while asset use has no effect on asset optimization. In addition, asset utilization has a significant and positive effect on asset optimization.
\end{abstract}

Article Histori:

Accepted: $23 / 2 / 2021$

Review: 4/4/2021

Publish: 30/4/2021

Keyword: Asset Inventory, Asset Optimization, Asset Security, Asset Use, Asset Utilization, Maintenance

\section{PENDAHULUAN}

Aset daerah adalah potensi ekonomi bagi pemerintah daerah dan merupakan bagian penting yang mutlak diperlukan dalam penyelenggaraan pemerintahan daerah. Aset daerah harus dapat dikelola dengan baik, karena dapat memberikan kontribusi bagi pemerintah daerah baik itu 
sebagai sumber pendapatan untuk menunjang peran dan fungsi pemerintah daerah sebagai pemberi pelayanan daerah kepada masyarakat atau sebagai dasar tertib penyusunan laporan keuangan pemerintah daerah. Pengelolaan aset daerah secara transparan, efektif, efisien, dan akuntabel sudah menjadi tuntutan dalam rangka pelayanan masyarakat yang lebih optimal. Menurut Noviawati (2016) pengelolaan dan pemanfaatan aset daerah yang optimal memicu pertumbuhan ekonomi daerah, sehingga berdampak pada peningkatan Pendapatan Asli Daerah (PAD) serta peningkatan kepercayaan masyarakat kepada pemerintah daerah dalam hal pengelolaan keuangan negara.

Sejak masa reformasi, dalam menjalankan roda pemerintahan sekarang ini berbagai terobosan telah terjadi. Banyak perubahan-perubahan yang telah dilakukan baik di level pemerintah pusat maupun pemerintah daerah tetapi masih ada juga persoalan-persoalan yang muncul dalam pembangunan di berbagai bidang, baik di tingkat pusat maupun daerah. Persoalan yang sering terjadi adalah persoalan yang menyangkut dengan keuangan dan aset di mana sampai saat ini belum dilaksanakan secara optimal, efektif dan efisien dalam tata pengelolaannya. Dengan demikian tidak disangkal bahwa masih ada banyak daerah provinsi/kabupaten/kota di Indonesia yang sampai saat ini belum juga mendapatkan opini Wajar Tanpa Pengecualian (WTP) dari Badan Pemeriksa Keuangan (BPK) Republik Indonesia (RI). Hal ini ditunjukkan oleh penelitian yang dilakukan oleh Chodariyanti (2019), bahwa pada Pemerintah Kabupaten Lamongan masih mendapatkan opini Wajar Dengan Pengecualian (WDP) oleh Badan Pemeriksa Keuangan Republik Indonesia (BPK-RI) dikarenakan masih terdapat permasalahan pada inventarisasi aset daerah yang pengolahan datanya masih kurang baik dan tanah belum tersertifikasi, disamping sumber daya manusia yang kurang berkualitas, perlu pemahaman sistem informasi manajemen daerah dalam pengelolaan aset daerah untuk mempermudah proses pengelolaannya. Selain itu hasil pemeriksaan Badan Pemeriksa Keuangan (BPK) Republik Indonesia (RI) bagi pemerintah daerah yang sudah memperoleh opini Wajar Tanpa Pengecualian (WTP) tidak menjadikan jaminan bahwa pengelolaan aset sudah dikelola dengan baik, sehingga tetap diperlukan optimalisasi dalam manajemen aset pemerintah daerah agar semakin optimal dalam menunjang tugas dan fungsi pemerintah daerah.

Manajemen aset merupakan upaya untuk memandu pengelolaan kekayaan yang mencakup proses perencanaan kebutuhan aset, mendapatkan, inventarisasi, legal audit, menilai, mengoperasikan, memelihara, membaharukan atau menghapuskan, hingga mengalihkan aset secara efektif dan efisien. Dengan adanya manajeman aset diharapkan dapat mendorong tercapainya optimalisasi aset tetap tanah menjadi lebih efektif dan efisien dalam rangka menunjang tugas dan fungsi pemerintah daerah (Purba, 2019). Namun, sistem manajemen aset dinilai belum memberikan dampak kemajuan bagi peningkatan pelayanan di lingkungan kerja pemerintah daerah masing-masing dan manajemen aset selama ini masih kurang diperhatikan dalam birokrasi pemerintah daerah, padahal hampir semua pemerintah daerah tidak memperoleh opini Wajar Tanpa Pengecualian (WTP) dikarenakan pengelolaan aset yang tidak sesuai dengan ketentuan yang diatur dalam Peraturan Pemerintah Nomor 27 Tahun 2014 tentang Pengelolaan Barang Milik Negara/Daerah dan Peraturan Menteri Dalam Negeri 
Nomor 19 Tahun 2016 tentang Pedoman Pengelolaan Barang Milik Daerah. Menurut Chodariyanti (2019) Pemerintah Kabupaten Lamongan masih mendapatkan opini Wajar Dengan Pengecualian (WDP) oleh Badan Pemeriksa Keuangan Republik Indonesia (BPK-RI) dikarenakan masih terdapat permasalahan pada inventarisasi aset daerah yang pengolahan datanya masih kurang baik dan tanah belum tersertifikasi, disamping sumber daya manusia yang kurang berkualitas, perlu pemahaman sistem informasi manajemen daerah dalam pengelolaan aset daerah untuk mempermudah proses pengelolaannya. Menurut Chodariyanti (2019) Pemerintah Kabupaten Lamongan masih mendapatkan opini Wajar Dengan Pengecualian (WDP) oleh Badan Pemeriksa Keuangan Republik Indonesia (BPK-RI) dikarenakan masih terdapat permasalahan pada inventarisasi aset daerah yang pengolahan datanya masih kurang baik dan tanah belum tersertifikasi, disamping sumber daya manusia yang kurang berkualitas, perlu pemahaman sistem informasi manajemen daerah dalam pengelolaan aset daerah untuk mempermudah proses pengelolaannya.

Optimalisasi aset adalah satu proses kerja dalam manajemen aset yang bertujuan untuk mengoptimalkan potensi fisik, nilai, jumlah/volume, lokasi, ekonomi, dan legal yang dimiliki aset tersebut (Siregar, 2004). Untuk melakukan optimalisasi aset harus dilakukan inventarisasi, penilaian serta pengkajian terhadap potensi aset yang ada dengan menghimpun semua jenis aset, baik aset bergerak maupun aset tidak bergerak. Inventarisasi dilakukan untuk mengetahui asal usul serta informasi yang berkaitan dengan aset mencakup luas, volume, spesifikasi, jenis, merk, dan harga perolehan dari aset (Asman et al., 2016; Pratama \& Pangayow, 2016).
Manajemen dan pengelolaan aset yang diambil dan dijadikan sebagai fokus pada penelitian ini adalah pengaruh inventarisasi aset, penggunaan aset, pengamanan dan pemeliharaan aset terhadap optimalisasi aset tetap tanah pada Pemerintah Kabupaten Malang khususnya pada Badan Keuangan dan Aset Daerah Kabupaten Malang dimana juga berfungsi sebagai Pembantu Pengelola Barang atau disebut juga Pejabat Penatausahaan Barang. Pengelolaan aset tetap tanah merupakan salah satu unsur yang sangat penting dalam menunjang tugas dan fungsi serta pelayanan organisasi perangkat daerah terkait disamping itu dengan semakin berkembangnya Kabupaten Malang akan sangat rentan terhadap sengketa tanah baik itu dengan pemerintah pusat, pemerintah provinsi, pemerintah desa, dengan masyarakat maupun dengan pihak-pihak lainnya di samping itu Pemerintah Kabupaten Malang pada tahun 2018 memperoleh opini Wajar Tanpa Pengecualian (WTP) tetapi tetap mendapatkan catatan terkait pengelolaan aset tetap tanah

Dalam Peraturan Menteri Dalam Negeri Nomor 19 Tahun 2016 tentang Pedoman Pengelolaan Barang Milik Daerah, penggunaan aset adalah kegiatan yang dilakukan oleh pengguna barang/ organisasi perangkat daerah dalam mengelola dan menatausahakan barang milik daerah yang sesuai dengan tugas dan fungsi organisasi perangkat daerah yang bersangkutan. Sedangkan pengamanan dan pemeliharaan aset adalah kegiatan untuk mengamankan barang milik daerah baik itu pengamanan secara fisik, administrasi dan pengamanan hukum. Pemeliharaan adalah kegiatan untuk menjaga kondisi dan memperbaiki semua barang milik daerah agar selalu dalam keadaan baik dan layak 
serta siap digunakan secara berdaya guna dan berhasil guna.

Pengelolaan aset yang dijadikan sebagai fokus dalam penelitian ini adalah upaya untuk menata kembali manajemen aset yang merupakan salah satu faktor penentu kinerja daerah dalam rangka mengoptimalkan berbagai potensi aset yang ada sekaligus sebagai langkah untuk memberikan motivasi kerja dalam lingkup pemerintah daerah, khususnya di Badan Keuangan dan Aset Daerah Kabupaten Malang.

Beberapa penelitian membuktikan bahwa inventarisasi, pemanfaatan aset, penilaian, pengawasan dan pengendalian kondisi aset berpengaruh terhadap optimalisasi aset (Hartati et al., 2019; Pauweni et al., 2017; Wombaibabo, 2017; Demetouw et al., 2016). Lebih jauh penelitian-penelitian tersebut juga membuktikan bahwa manajemen aset terutama tanah dan bangunan milik pemerintah daerah apabila dioptimalkan dapat meningkatkan pelayanan kepada masyarakat (public service) sebagai perwujudan atas pembangunan yang berkelanjutan dan tata kelola pemerintah yang baik (good governance). Hasil yang berbeda ditemukan oleh Antoh (2017) bahwa manajemen aset berupa inventarisasi aset, dan penilaian aset tidak berpengaruh positif dan signifikan terhadap optimalisasi aset tetap (tanah dan bangunan) sedangkan legal audit dan pengawasan dan pengendalian terbukti berpengaruh positif dan signifikan. Mahsun (2003) menemukan bahwa praktek manajemen aset pada Pemerintah Kota Yogyakarta belum optimal karena belum memiliki kapasitas yang memadai untuk mengelola aset yang dimiliki terutama aset yang berukuran sangat besar dan jangkauannya tersebar di mana-mana.
Dengan adanya perbedaaan penelitian sebelumnya dan perkembangan manajemen aset pada era saat ini, maka motivasi penelitian ini bertujuan untuk memberikan bukti empiris pengaruh manajemen aset terhadap optimalisasi aset tetap tanah pada Pemerintah Kabupaten Malang.

\section{KAJIAN LITERATUR}

Sehubungan dengan diberlakukanya Peraturan Pemerintah Nomor 6 Tahun 2006 yang telah dirubah dengan Peraturan Pemerintah Nomor 27 Tahun 2014 tentang Pengelolaan Barang Milik Negara/Daerah dan Peraturan Menteri Dalam Negeri Nomor 17 Tahun 2007 tentang Pedoman Teknis Pengelolaan Barang Milik Daerah yang telah dirubah dengan Peraturan Menteri Dalam Negeri Nomor 19 Tahun 2016 tentang Pedoman Pengelolaan Barang Milik Daerah. Pengelolaan aset daerah adalah tidak sekedar administratif semata, tetapi lebih maju berfikir dalam menangani dan mengoptimalisasi penggunaan aset daerah, serta bagaimana meningkatkan efisiensi, efektivitas dan menciptakan nilai tambah dalam mengelola aset. Oleh karena itu, lingkup pengelolaan aset daerah mencakup perencanaan kebutuhan dan penganggaran, pengadaan, penggunaan, pemanfaatan, pengamanan dan pemeliharaan, penilaian, penghapusan, pemindahtanganan, pemusnahan, penatausahaan, pembinaan, pengawasan dan pengendalian.

Phelps (2009), meneliti hubungan antara pemikiran, praktek dan hasil dalam pengelolaan aset dalam rangka memahami faktor-faktor perubahan dari manajemen properti untuk manajemen aset yang terjadi di Inggris dan Rusia. Sebuah kerangka kerja analitis dikembangkan untuk mengukur mengapa organisasi melakukan manajemen aset; bagaimana mereka melakukannya dan apa yang mereka capai. Kesimpulannya manajemen aset di Inggris lebih maju dan 
disiplin dibandingkan Rusia, ini disebabkan adanya campur tangan pemerintah pusat dan keterlibatan aktif para pelaku manajemen aset. Sriastiti et al. (2020), melakukan penelitian pengaruh manajemen aset yang meliputi kebutuhan perencanaan, inventaris, identifikasi, audit hukum, penilaian aset, pemanfaatan, pengawasan dalam optimalisasi aset. Dari hasil penelitian diperoleh hasil perencanaan kebutuhan, penilaian aset, dan pemanfaatan berpengaruh terhadap optimalisasi aset, sedangkan inventarisasi, identifikasi, audit hukum, dan pengawasan tidak berpengaruh terhadap optimalisasi aset.

Siregar (2004) tahapan manajemen aset daerah meliputi: Inventarisasi, Legal Audit, Penilaian Aset, Optimalisasi Aset, pengawasan dan pengendalian aset yang kemudian dikembangkan dalam siklus barang milik daerah sesuai Permendagri 19 Tahun 2016 dimana manajemen aset meliputi perencanaan kebutuhan inventarisasi aset, penggunaan aset, pengamanan dan pemeliharaan aset, pemanfaatan aset, penatausahaan aset dan penghapusan aset.

Siregar (2004) menyatakan aset adalah barang (thing) atau sesuatu barang (anything) yang mempunyai nilai ekonomi (economic value), nilai komersial (commercial value) atau nilai tukar (exchange value) yang dimiliki oleh badan usaha, instansi atau individu (perorangan). Pengertian aset yang disebutkan di atas pada dasarnya berlaku pula untuk aset yang dikuasai atau dimiliki negara berdasarkan syarat-syarat tertentu.

Surminah (2008) menyatakan bahwa manajemen aset adalah "suatu sistem penatalaksanaan atau suatu unit fungsional yang berfungsi/bertugas untuk mengoperasikan seperangkat sumber daya (sumber daya manusia, uang, mesin, barang, waktu) dan seperangkat instrument (metode, standar/kriteria) untuk mencapai satu tujuan. Kebutuhan akan manajemen aset menjadi penting yang berhubungan dengan ketersediaan, efisiensi, mutu, kesinambungan perusahaan dan pemenuhan keselamatan lingkungan) aset fisik yang dimiliki perusahaan".

Peraturan Menteri Dalam Negeri Republik Indonesia Nomor 19 Tahun 2016 tentang Pedoman Pengelolaan Barang Milik Daerah, tahapan pengelolaan manajemen aset daerah meliputi, pengadaan, penggunaan, pemanfaatan, pengamanan dan pemeliharaan, penilaian, pemindahtanganan, pemusnahan, penghapusan, penatausahaan, dan pembinaan, pengawasan dan pengendalian.

Pemanfaatan adalah "pendayagunaan barang milik daerah yang tidak digunakan untuk penyelenggaraan tugas dan fungsi SKPD dan/atau optimalisasi barang milik daerah dengan tidak mengubah status kepemilikan. Pemanfaatan barang milik daerah dilaksanakan berdasarkan pertimbangan teknis dengan memperhatikan kepentingan daerah dan kepentingan umum serta tidak menggangu pelaksanaan tugas dan fungsi penyelenggaraan pemerintah daerah".

Optimalisasi aset merupakan sebuah proses kerja dalam manajemen aset dalam rangka mendayagunakan aset baik secara penggunaan aset maupun secara pemanfaatan aset. Berdasarkan pendapat tersebut dapat disimpulkan bahwa optimalisasi adalah pengoptimalan pemanfaatan potensi dari sebuah aset yang dimana dapat menghasilkan manfaat yang lebih atau juga mendatangkan pendapatan.

\section{METODE PENELITIAN}

Lokasi penelitian pengaruh inventarisasi aset, penggunaan aset, pengamanan dan pemeliharaan aset terhadap optimalisasi aset tanah pada Pemerintah Kabupaten Malang berada di 
Badan Keuangan dan Aset Daerah Kabupaten Malang dengan melibatkan 62 (enam puluh dua) Organisasi Perangkat Daerah. Objek aset tanah milik Pemerintah Kabupaten Malang tersebar di 33 (tiga puluh tiga) kecamatan.

Pada penelitian ini ada variable bebas (independent variable) dan variabel terikat (dependent variable), variabel bebas pada penelitian ini adalah Inventarisasi Aset $\left(X_{1}\right)$, Penggunaan Aset $\left(X_{2}\right)$ dan Pengamanan dan Pemeliharaan Aset $\left(X_{3}\right)$. Sedangkan variable terikatnya pada penelitian ini adalah Pemanfaatan Aset $\left(Y_{1}\right)$ dan Optimalisasi Aset $\left(\mathrm{Y}_{2}\right)$. Penjelasan dan indikator pengukuran masing-masing variabel disajikan pada Tabel 1.

Tabel 1. Definisi Variabel dan Indikator Pengukuran Variabel Penelitian

\begin{tabular}{|c|c|}
\hline Variabel & Pengertian \& Indikator Pengukuran \\
\hline Inventarisasi Aset $\left(\mathrm{X}_{1}\right)$ & $\begin{array}{l}\text { Inventarisasi adalah rangkaian kegiatan yang meliputi pembukuan, } \\
\text { inventarisasi, dan pelaporan barang milik daerah sesuai dengan ketentuan } \\
\text { peraturan perundang-undangan. Pengguna Barang dalam hal ini Kepala } \\
\text { Organisasi Perangkat Daerah melakukan inventarisasi barang milik daerah } \\
\text { paling sedikit } 1 \text { (satu) kali dalam } 5 \text { (lima) tahun, adapaun indikatornya adalah } \\
\text { apakah pencatatan aset dilakukan secara rinci dan Inventarisasi dilakukan secara } \\
\text { periodik dan berkelanjutan. }\end{array}$ \\
\hline Penggunaan Aset $\left(\mathrm{X}_{2}\right)$ & $\begin{array}{l}\text { Penggunaan adalah kegiatan yang dilakukan oleh Pengguna Barang dalam } \\
\text { mengelola dan menatausahakan barang milik daerah yang sesuai dengan tugas } \\
\text { dan fungsi SKPD yang bersangkutan. Indikatornya adalah aset digunakan untuk } \\
\text { mendukung tugas dan fungsi, apakah terdapat idle capacity/tidak dioptimalkan. }\end{array}$ \\
\hline Peng & Pengamanan dan pemeliharaan barang milik daerah wajib dilakukan oleh \\
\hline Pemeliharaan Ase & $\begin{array}{l}\text { Pengguna Barang yang berada dalam penguasaannya. Pengamanan barang milik } \\
\text { daerah meliputi pengamanan fisik, administrasi dan hukum. Indikatornya } \\
\text { adalah pengamanan fisik, pengamanan administrasi, pengamanan hukum, dan } \\
\text { melaporkan kondisi barang hasil pemeliharaannya. }\end{array}$ \\
\hline Pemanfaatan Aset $\left(\mathrm{Y}_{1}\right)$ & $\begin{array}{l}\text { Pemanfaatan adalah pendayagunaan barang milik daerah yang tidak digunakan } \\
\text { untuk penyelenggaraan tugas dan fungsi SKPD dan/atau optimalisasi barang } \\
\text { milik daerah dengan tidak mengubah status kepemilikan. Pemanfaatan barang } \\
\text { milik daerah dilaksanakan berdasarkan pertimbangan teknis dengan } \\
\text { memperhatikan kepentingan daerah dan kepentingan umum serta tidak } \\
\text { menggangu pelaksanaan tugas dan fungsi penyelenggaraan pemerintah daerah. } \\
\text { Indikatornya adalah Penyusunan data barang milik daerah, potensi peluang } \\
\text { pemanfaatan, kemampuan aste untuk dioptimalkan dan memiliki rancangan } \\
\text { optimalisasi pemanfaatan. }\end{array}$ \\
\hline Optimalisasi Aset $\left(\mathrm{Y}_{2}\right)$ & $\begin{array}{l}\text { Optimalisasi aset merupakan sebuah proses kerja dalam manajemen aset dalam } \\
\text { rangka mendayagunakan aset baik secara penggunaan aset maupun secara } \\
\text { pemanfaatan aset. Optimizing the utilization of assets in term of service benefit dan } \\
\text { financial return. Indikator optimalisasi aset adalah mengoptimalkan secara fisik } \\
\text { aset tanah, mengoptimalkan lokasi aset tetap tanah tersebut berada, } \\
\text { mengoptimalkan nilai/jumlah/volume dari aset tetap tanah, mengoptimalkan } \\
\text { legal aset dan mengoptimalkan secara ekonomi aset tetap tanah }\end{array}$ \\
\hline
\end{tabular}

Instrumen penelitian yang digunakan dalam penelitian ini menggunakan skala likert. Skala ini digunakan untuk mengukur pendapat, persepsi, sikap, dan asumsi seseorang atau kelompok orang tentang fenomena sosial. Item instrument yang digunakan adalah sebagai berikut: $\mathrm{SS}=$ sangat setuju diberi skor $=5 ; \mathrm{S}=$ setuju diberi skor $=4 ; \mathrm{N}=$ netral diberi skor $=3$; $\mathrm{TS}=$ 
tidak setuju diberi skor= 2; $\mathrm{STS}=$ sangat tidak setuju diberi skor $=1$.

Pengujian yang digunakan oleh peneliti dalam mengungkap permasalahan adalah menggunakan uji validitas dengan tingkat kepercayaan $\alpha=5 \%$.

$\mathrm{r}=\frac{n\left(\sum X Y\right)-\left(\sum X\right)\left(\sum Y\right)}{\sqrt{n\left(\sum X^{2}\right)-\left(\sum X\right)^{2}} \sqrt{n\left(\sum Y^{2}\right)-\left(\sum Y\right)^{2}}}$

Uji reliabilitas untuk menunjukan sejauh mana hasil pengukuran tetap konsisten dan handal.

$$
\mathrm{r}=\frac{K}{K-1}\left(\frac{1-\sum \sigma 1^{2}}{\sigma^{2}}\right)
$$

Populasi dalam penelitian ini adalah Aparatur Sipil Negara (ASN) yang memiliki kriteria antara lain sebagai berikut: memiliki jabatan sebagai Pejabat Penatausahaan Pengguna Barang/Pengurus Barang Pengguna yang tecantum dalam Surat Keputusan Bupati Malang dan berada pada Organisasi Perangkat Daerah yang memiliki aset tetap berupa tanah. Penelitian dilakukan terhadap 62 (enam puluh dua) Pejabat Penatausahaan Barang/Pengurus Barang pada organisasi perangkat daerah yang memiliki aset tetap tanah. Teknik pengumpulan data pada masa pandemi COVID-19 dengan menyebarkan kuesioner kepada responden baik secara online maupun secara offline dengan mendatangi langsung ke Organisasi Perangkat Daerah.

Teknik analisis data yang digunakan dalam penelitian ini adalah analisis Regresi Linear Berganda digunakan untuk mengetahui pengaruh inventarisasi aset, penggunaan aset dan pengamanan dan pemeliharaan aset terhadap pemanfaatan aset, pengaruh inventarisasi aset, penggunaan aset dan pengamanan dan pemeliharaan aset terhadap optimalisasi aset dan pengaruh pemanfaatan aset terhadap optimalisasi aset, digunakan regresi linier berganda dengan bantuan program SPSS dengan persamaan:

$Y_{1}=a+\beta_{1} X_{1}+\beta_{2} X_{2}+\beta_{3} X_{3}+\varepsilon$

$Y_{2}=a+\beta_{4} X_{1}+\beta_{5} X_{2}+\beta_{6} X_{3}+\beta_{7} Y_{1}+\varepsilon$

$Y_{2}=a+\beta_{7} Y_{1}$

Keterangan

$\mathrm{Y}_{1}$ : Pemanfaatan aset

$\mathrm{X}_{1}$ : Inventarisasi aset

$\mathrm{Y}_{2}$ : Optimalisasi aset

$\mathrm{X}_{2}$ : Penggunaan aset

a : Bilangan konstanta

$\mathrm{X}_{3}$ : Pengamanan dan pemeliharaan aset

$\beta_{1} \ldots \ldots \beta_{7}$ : Koefisien regresi

$\varepsilon$ : Variabel pengganggu

Path Analysis atau Analisis Jalur digunakan untuk menganalisis pola hubungan diantara variabel. Model ini untuk mengetahui pengaruh langsung maupun tidak langsung seperangkat variabel bebas (eksogen) terhadap variabel terikat (endogen).

\section{HASIL DAN PEMBAHASAN Hasil}

Dari ringkasan hasil test validitas membuktikan bahwa tingkat validitas suatu instrumen diukur berdasarkan perbanding nilai korelasi tabel (rtabel) masing-masing indikator. Untuk nilai korelasi Pearson's product moment pada $\mathrm{a}=0,05$ dengan $\mathrm{N}=62$ adalah sebesar 0,250. Berdasarkan hasil olah data menggunakan aplikasi SPSS 16.0 dari 5 variabel dengan 35 item pernyataan, semua pernyataan tersebut adalah valid dengan didasarkan kepada pengambilan keputusan menggunakan perbandingan $r_{\text {hitung }}>r_{\text {tabel, }}$ sehingga dapat disimpulkan bahwa instumen yang digunakan dalam penelitian ini telah memenuhi persyaratan uji validitas.

Untuk mengukur tingkat reliabilitas pada penelitian ini adalah menggunakan nilai koefisien dengan bersandar pada tafsiran pedoman tentang kriteria 
keterandalan yang dikemukakan oleh Arikunto, (2010) bahwa suatu variabel dikatakan reliabel apabila nilai koefisien alpha sebesar 0,60-0,70. Hasil uji reliabilitas dapat dilihat pada Tabel 2.

Tabel 2. Nilai Koefisien Reliabilitas

\begin{tabular}{lcc}
\hline \multicolumn{1}{c}{ Variabel } & $\begin{array}{c}\text { Koefisien } \\
\text { Reliabilitas }\end{array}$ & Ket \\
\hline Inventarisasi Aset & 0,653 & Reliabel \\
Penggunaan Aset & 0,585 & Reliabel \\
Pengamanan dan & 0,865 & Reliabel \\
Pemeliharaan Aset & 0,873 & Reliabel \\
Pemanfaatan Aset & 0,765 & Reliabel \\
Optimalisasi Aset & & \\
\hline
\end{tabular}

Hasil uji normalitas menunjukan bahwa titik terlihat menyebar dan mengarah kekanan atas mengikuti arah garis diagonal sehingga kesimpulannya data tersbut memiliki sebaran normal dan model regresi yang digunakan dalam penelitian ini dapat diterima. Hasil uji multikolinieritas membuktikan bahwa Inventarisasi Aset $\left(X_{1}\right)$ Penggunaan Aset $\left(X_{2}\right)$, dan Pengamanan dan Pemeliharaan Aset $\left(X_{3}\right)$ nilai Varians Inflation Factor (VIF) kurang dari 10 sehingga dapat disimpulkan tidak terjadi multikolinieritas dan dapat dikatakan pengujian dalam model regresi tersebut terpercaya. Hasil uji heterokedastisitas menunjukan plot data yang menyebar secara acak dan tidak ada pola yang jelas maka dapat disimpulkan bahwa variabel bebas adalah homogeny dan tidak terjadi heteroskedastisitas.

Hasil uji bebas autokorelasi inventarisasi aset, penggunaan aset, serta pengamanan dan pemeliharaan aset terhadap pemanfaatan aset menyatakan bahwa nilai DW $(2,514)$ terletak antara dU $(1,7671)$ dan 4-dU $(2,2329)$ maka tidak terjadi autokorelasi. Hasil uji bebas autokorelasi inventarisasi aset, penggunaan aset, serta pengamanan dan pemeliharaan aset terhadap optimalisasi aset menyatakan bahwa nilai DW $(1,994)$ terletak antara dU
$(1,7671)$ dan 4-dU $(2,2329)$ maka tidak terjadi autokorelasi. Hasil uji bebas autokorelasi inventarisasi aset, penggunaan aset, serta pengamanan dan pemeliharaan aset terhadap optimalisasi aset menyatakan bahwa nilai DW $(1,994)$ terletak antara dU $(1,7671)$ dan 4-dU $(2,2329)$ maka tidak terjadi autokorelasi. Hasil uji bebas autokorelasi pemanfaatan aset terhadap optimalisasi aset menyatakan bahwa nilai DW $(1,591)$ terletak antara dU $(1,7671)$ dan 4-dU $(2,2329)$ maka tidak terjadi autokorelasi.

Hasil analisis regresi linear berganda tentang pengaruh inventarisasi aset, penggunaan aset dan pengamanan dan pemeliharaan aset terhadap pemanfaatan aset ditunjukkan pada Tabel 3 .

Tabel 3. Hasil Pengujian Regresi Persamaan Struktural 1

\begin{tabular}{lcrl}
\hline \multicolumn{1}{c}{ Variabel Dependen } & Beta & t & Sig. \\
\hline Constant & & 1,018 & 0,313 \\
Inventarisasi Aset & $-0,143$ & $-1,206$ & 0,233 \\
Penggunaan Aset & 0,157 & 1,243 & 0,219 \\
Pengamanan dan & 0,398 & 3,203 & 0,002 \\
Pemeliharaan Aset & & & \\
\hline
\end{tabular}

Variabel Dependen: Pemanfaatan Aset. (Signikansi pada $\alpha=5 \%$ )

Hasil analisis regresi berganda pengaruh inventarisasi aset, penggunaan aset, pengamanan dan pemeliharaan aset terhadap pemanfaatan aset dengan nilai Sig $(p) \geq 0,05(\alpha=5 \%)$ maka inventarisasi aset dan penggunaan aset tidak berpengaruh terhadap pemanfaatan aset, sedangkan Sig $(p) \leq 0,05(a=5 \%)$ maka pengamanan dan pemeliharaan aset berpengaruh terhadap pemanfaatan aset.

Hasil analisis regresi linear berganda tentang pengaruh inventarisasi aset, penggunaan aset dan pengamanan dan pemeliharaan aset terhadap optimalisasi aset ditunjukkan pada Tabel 4 . 
Tabel 4. Hasil Pengujian Regresi Persamaan Struktural 2

\begin{tabular}{lccc}
\hline Variabel Dependen & Beta & $\mathbf{t}$ & Sig. \\
\hline Constant & & 0,019 & 0,985 \\
Inventarisasi Aset & 0,351 & 3,093 & 0,003 \\
Penggunaan Aset & 0,042 & 0,348 & 0,729 \\
Pengamanan dan & 0,348 & 2,917 & 0,005 \\
Pemeliharaan Aset & & &
\end{tabular}

Variabel Dependen: Optimalisasi Aset. (Signikansi pada a $=5 \%)$

Hasil analisis regresi berganda pengaruh inventarisasi aset, penggunaan aset, pengamanan dan pemeliharaan aset terhadap optimalisasi aset dengan nilai Sig $(p) \geq 0,05(a=5 \%)$ maka penggunaan aset tidak berpengaruh terhadap pemanfaatan aset, sedangkan Sig $(p) \leq 0,05(\alpha=5 \%)$ maka inventarisasi aset dan pengamanan dan pemeliharaan aset berpengaruh terhadap optimalisasi aset. Hasil analisis regresi berganda pengaruh pemanfaatan aset terhadap optimalisasi aset ditunjukkan pada Tabel 5.
Tabel 5. Hasil Pengujian Regresi Persamaan Struktural 3

\begin{tabular}{lccc}
\hline \multicolumn{1}{c}{ Variabel Dependen } & Beta & t & Sig. \\
\hline Constant & & 7,314 & 0,000 \\
Pemanfaatan Aset & 0,450 & 3,901 & 0,000 \\
\hline Variabel Dependen: Optimalisasi Aset. (Signikansi pada a \\
$=5 \%)$
\end{tabular}

Hasil analisis regresi berganda pengaruh pemanfaatan aset terhadap optimalisasi aset dengan sig $(p) \leq 0.05$ ( $\alpha=$ $5 \%$ ) maka pemanfaatan aset berpengaruh terhadap optimalisasi aset.

Untuk menguji pengaruh langsung dan tidak langsung antara variabel pengaruh inventarisasi aset, penggunaan aset dan pengamanan dan pemeliharaan aset terhadap optimalisasi aset melalui pemanfaatan aset digunakan pengujian Analisis Jalur (Path Analysis). Adapun hasil uji Analisis Jalur ditunjukkan pada Tabel 6.

Tabel 6. Ringkasan Hasil Analisis Jalur

\begin{tabular}{|c|c|c|c|}
\hline Variabel & $\begin{array}{l}\text { Pengaruh } \\
\text { Langsung }\end{array}$ & $\begin{array}{l}\text { Pengaruh Tidak } \\
\text { Langsung }\end{array}$ & $\begin{array}{l}\text { Pengaruh } \\
\text { Total }\end{array}$ \\
\hline Inventarisasi Aset (X1) $\rightarrow$ Pemanfaatan (Y1) & $-0,143$ & & $-0,143$ \\
\hline Penggunaan Aset $(\mathrm{X} 2) \rightarrow$ Pemanfaatan $(\mathrm{Y} 1)^{\prime}$ & 0,157 & & 0,157 \\
\hline Pengamanan dan Pemeliharaan $(\mathrm{X} 3) \rightarrow$ & 0,398 & & 0,398 \\
\hline Pemanfaatan (Y1) & & & \\
\hline Inventarisasi Aset (X1) $\rightarrow$ Optimalisasi Aset (Y2) & 0,351 & & 0,351 \\
\hline Penggunaan Aset $(\mathrm{X} 2) \rightarrow$ Optimalisasi Aset $(\mathrm{Y} 2)$ & 0,042 & & 0,042 \\
\hline Pengamanan Dan Pemeliharaan $(\mathrm{X} 3) \rightarrow$ & 0,348 & & 0,348 \\
\hline Optimalisasi Aset(Y2) & & & \\
\hline Pemanfaatan (Y1) $\rightarrow$ Optimalisasi Aset (Y2) & 0,450 & & 0,450 \\
\hline $\begin{array}{l}\text { Inventarisasi Aset }(\mathrm{X} 1) \rightarrow \text { Pemanfaatan }(\mathrm{Y} 1) \rightarrow \\
\text { Optimalisasi Aset }(\mathrm{Y} 2)\end{array}$ & & $-0,143 \times 0,450=-0,064$ & 0,286 \\
\hline $\begin{array}{l}\text { Penggunaan Aset }(\mathrm{X} 2) \rightarrow \text { Pemanfaatan }(\mathrm{Y} 1) \rightarrow \\
\text { Optimalisasi Aset }(\mathrm{Y} 2)\end{array}$ & & $0,157 \times 0,450=0,071$ & 0,113 \\
\hline $\begin{array}{l}\text { Pengamanan Dan Pemeliharaan }(\mathrm{X} 3) \rightarrow \\
\text { Pemanfaatan }(\mathrm{Y} 1) \rightarrow \text { Optimalisasi Aset }(\mathrm{Y} 2)\end{array}$ & & $0,398 \times 0,450=0,179$ & 0,527 \\
\hline
\end{tabular}

Tabel 6 menunjukkan bahwa untuk jalur pengaruh tidak langsung dari variabel Inventariasi aset terhadap optimalisasi aset melalui pemanfaatan aset menunjukan nilai sebesar 0,286, nilai total tersebut cenderung lebih kecil dari jalur pengaruh langsung variabel inventarisasi aset terhadap optimalisasi aset dengan total nilai sebesar 0,351. Sedangkan nilai pengaruh tidak langsung dari variabel penggunaan aset terhadap optimalisasi aset melalui pemanfaatan menunjukkan nilai total 
sebesar 0,113. Angka tersebut cenderung lebih besar jika dibandingkan dengan total nilai pada jalur pengaruh langsung yaitu 0,042 dari variabel penggunaan aset terhadap optimalisasi aset. Begitu juga dengan jalur pengaruh tidak langsung variabel pengamanan dan pemeliharaan terhadap optimalisasi aset melalui pemanfaatan dengan total nilai sebesar 0,527 yang cenderung lebih besar dari total nilai pada jalur pengaruh langsung pengamanan dan pemeliharaan terhadap optimalisasi aset dengan total nilai sebesar 0,348 . Oleh karena itu berdasarkan kalkulasi dan perbandingan nilai total pada jalur pengaruh langsung dan pengaruh tidak langsung maka dapat disimpulkan bahwa jalur yang paling kuat dan memiliki pengaruh yang signifikan terhadap optimalisasi aset terletak pada jalur pengaruh tidak langsung yaitu variabel pengamanan dan pemeliharaan terhadap optimalisasi aset melalui pemanfaatan dengan total nilai sebesar 0,527.

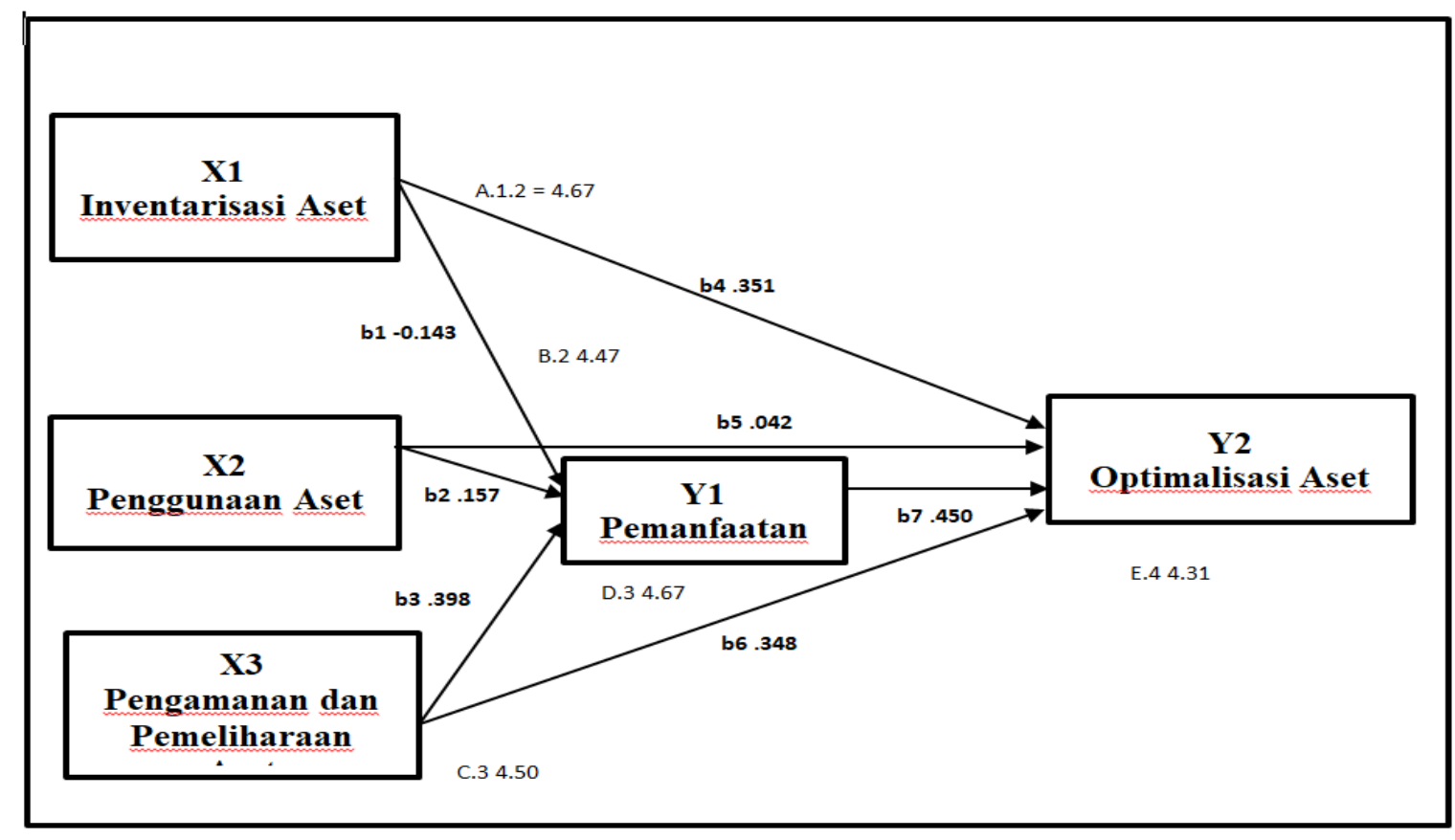

Gambar 1. Analisis Jalur Pengaruh Inventarisasi Aset, Penggunaan Asset, serta Pengamanan dan Pemeliharaan Aset terhadap Optimalisasi Aset Melalui Pemanfaatan Aset

\section{Pembahasan}

Pengaruh inventarisasi aset, penggunaan aset dan pengamanan dan pemeliharaan aset terhadap pemanfaatan aset di Pemerintah Kabupaten Malang

Inventarisasi aset tidak berpengaruh siginifikan terhadap pemanfaatan aset. Inventarisasi aset yang dilakukan secara periodik dan berkelanjutan meliputi inventarisasi/ pendataan barang milik daerah berupa aset tanah dilakukan secara periodik paling lama 5 (lima) tahun sekali dan melakukan perubahan data tanah apabila mengalami perubahan kondisi dan status penggunaannya ternyata tidak memiliki pengaruh terhadap pemanfaatan aset dimana yang paling utama dalam pemanfaatan aset adalah penyusunan data barang milik daerah yang terperinci dan sudah memiliki legalitas sertifikat dalam mendukung pemanfaatan. Sehingga yang perlu ditingkatkan oleh Pemerintah Kabupaten Malang agar inventarisasi aset berpengaruh terhadap pemanfaatan aset 
adalah pencatatan aset secara rinci yang meliputi pencatatan aset tanah dan mutasi perpindahan barangnya dilakukan secara rinci dan pencatatan aset tanah dilakukan secara tertib dengan dilengkapi identitas tanah (alamat/luas/bukti kepemilikan dan nilai perolehan).

Berdasarkan hasil yang diperoleh maka penggunaan aset tidak berpengaruh signifikan terhadap pemanfaatan aset di Organisasi Perangkat Daerah Kabupaten Malang. Terdapat aset idle capacity/tidak dioptimalkan berupa barang barang milik daerah berupa aset tanah akan diserahkan kembali kepada Bupati apabila tidak digunakan untuk penyelenggaraan tugas dan fungsi serta Organisasi Perangkat Daerah setiap tahun melaporkan aset yang tidak digunakan kepada Bupati kondisi dan status penggunaannya tidak memiliki tidak memiliki pengaruh terhadap pemanfaatan aset dimana yang paling utama dalam pemanfaatan aset adalah penyusunan data barang milik daerah yang terperinci dan sudah memiliki legalitas sertifikat dalam mendukung pemanfaatan.

Berdasarkan hasil yang diperoleh variabel pengamanan dan pemeliharaan aset berpengaruh signifikan dan positif terhadap pemanfaatan aset di Organisasi Perangkat Daerah Kabupaten Malang. Dalam variabel pengamanan dan pemeliharaan aset skor bobot tertinggi adalah pengamanan hukum dimana aset tanah disertifikatkan atas nama Pemerintah Kabupaten Malang dan melakukan perubahan apabila sertifikat yang dimiliki belum atas nama Pemerintah Kabupaten Malang, hal itu memicu dan mempengaruhi pemanfaatan aset dimana faktor terbesar terjadinya pemanfaatan aset adalah terkait data aset tercatat secara terperinci dan memiliki legalitas sertifikat untuk mendukung pemanfaatan aset.
Inventarisasi aset, penggunaan aset dan pengamanan dan pemeliharaan aset berpengaruh terhadap optimalisasi aset di Pemerintah Kabupaten Malang Malang

Berdasarkan hasil yang diperoleh maka variabel inventarisasi aset berpengaruh positif dan signifikan terhadap optimalisasi aset, hal ini menandakan bahwa Pencatatan aset tanah yang dilakukan secara rinci dan dilengkapi dengan identitas tanah (alamat/luas/bukti kepemilikan dan nilai perolehan) serta inventarisasi dilakukan secara periodik 5 (lima) tahun sekali dan melakukan perubahan data apabila terjadi perubahan kondisi memicu optimalisasi aset khususnya indikator mengoptimalkan legal aset tanah. Sehingga semakin tinggi pencatatan aset tanah secara rinci dan berkelanjutan maka aset tanah tersebut akan semakin optimal.

Variabel penggunanaan aset tidak berpengaruh positif dan signifikan terhadap optimalisasi aset. Oleh karena itu hasil dari penelitian ini menunjukan bahwa kurangnya laporan pengalihan status penggunaan barang milik daerah berupa aset tanah serta melaporkan aset yang tidak digunakan kepada Bupati menyebabkan aset tanah menjadi tidak optimal. Sehingga Pemerintah Kabupaten Malang harus lebih meningkatkan penggunaan aset untuk mendukung tugas dan fungsi Organisasi Perangkat Daerah agar lebih optimal.

Berdasarkan hasil yang diperoleh maka variabel pengamanan dan pemeliharaan aset berpengaruh signifikan dan positif terhadap optimalisasi aset di Organisasi Perangkat Daerah Kabupaten Malang. Oleh karena itu hasil pada penelitian ini menunjukan bahwa pengamanan dan pemeliharaan aset terkhususnya terkait pengamanan hukum atau kejelasan hukum dapat memicu optimalisasi aset dengan cara mengopti- 
malkan legal aset tersebut. Semua Aset tanah harus disertifikatkan atas nama Pemerintah Kabupaten Malang dan melakukan perubahan nama sertifikat apabila terdapat sertifikat belum atas nama Pemerintah Kabupaten Malang.

\section{Pemanfaatan Aset Berpengaruh terhadap Optimalisasi Aset di Pemerintah Kabupaten Malang}

Berdasarkan hasil yang diperoleh maka variabel pemanfaatan aset berpengaruh positif dan signifikan terhadap optimalisasi aset di Organisasi Perangkat Daerah Kabupaten Malang. Oleh karena itu hasil penelitian menunjukan bahwa pemanfaatan aset berupa data barang milik daerah, potensi peluang pemanfaatan, serta kemampuan aset untuk dioptimalkan berjalan searah dengan optimalisasi aset baik optimal secara fisik aset maupun optimal secara ekonomi, Sehingga semakin tinggi pemanfaatan aset maka aset tersebut semakin optimal. Hasil ini sejalan dengan penelitian yang dilakuka oleh Sriastiti (2020) dan Jusmin \& Nursalim (2018).

Untuk temuan pada penelitian ini adalah pengaruh tidak langsung dari variabel Inventariasi aset terhadap optimalisasi aset melalui pemanfaatan aset menunjukan nilai sebesar 0,286 . Nilai total tersebut cenderung lebih kecil dari jalur pengaruh langsung variabel inventarisasi aset terhadap optimalisasi aset dengan total nilai sebesar 0,351. Sedangkan nilai pengaruh tidak langsung dari variabel penggunaan aset terhadap optimalisasi aset melalui pemanfaatan menunjukan nilai total sebesar 0,113. Angka tersebut cenderung lebih besar jika dibandingkan dengan total nilai pada jalur pengaruh langsung yaitu 0,042 dari variabel penggunaan aset terhadap optimalisasi aset. Begitu juga dengan jalur pengaruh tidak langsung variabel pengamanan dan pemeliharaan terhadap optimalisasi aset melalui pemanfaatan dengan total nilai sebesar 0,527 yang cenderung lebih besar dari total nilai pada jalur pengaruh langsung pengamanan dan pemeliharaan terhadap optimalisasi aset dengan total nilai sebesar 0,348.

Oleh karena itu berdasarkan kalkulasi dan perbandingan nilai total pada jalur pengaruh langsung dan pengaruh tidak langsung maka dapat disimpulkan bahwa jalur yang paling kuat dan memiliki pengaruh yang signifikan terhadap optimalisasi aset terletak pada jalur pengaruh tidak langsung yaitu variabel pengamanan dan pemeliharaan terhadap optimalisasi aset melalui pemanfaatan dengan total nilai sebesar 0,527. Kejelasan hukum dalam variabel pengamanan dan pemeliharaan aset dapat memicu pemanfaatan aset serta berpengaruh terhadap optimalisasi, sehingga Pemerintah Kabupaten Malang perlu melakukan sebuah terobosan dan melakukan skala prioritas terkait legalisasi aset tanah agar semua aset tanah milik Pemerintah Kabupaten Malang bersertifikat atas nama Pemerintah Kabupaten Malang.

\section{PENUTUP}

Adapun hasil penelitian ini dapat disimpulkan bahwa manajemen aset berupa inventarisasi aset, penggunaan aset dan pengamanan dan pemeliharaan aset berpengaruh terhadap optimalisasi aset melalui pemanfaatan aset. Pengaruh langsung inventarisasi aset terhadap optimalisasi berpengaruh dan signifikan sedangkan pengaruh tidak langsung inventarisasi aset terhadap optimalisasi melalui pemanfaatan tidak berpengaruh dan tidak signifikan. Pengaruh penggunaan aset terhadap optimalisasi aset maupun pengaruh tidak langsung terhadap optimalisasi aset melalui pemanfaatan aset tidak berpengaruh dan tidak signifikan. 
Sedangkan pengaruh langsung pengamanan dan pemeliharaan aset terhadap optimalisasi dan pengaruh tidak langsung terhadap optimalisasi aset melalui pemanfaatan aset sama-sama berpengaruh dan signifikan dan pemanfaatan aset berpengaruh dan signifikan terhadap optimalisasi aset. Nilai tertinggi yang diperoleh adalah pengaruh tidak langsung pengamanan dan pemeliharaan aset terhadap optimalisasi melalui pemanfaatan aset sehingga legalisasi dokumen sertifikat tanah atas nama Pemerintah Kabupaten Malang mutlak dibutuhkan dalam rangka meningkatkan pemanfaatan aset agar dapat disusun secara terperinci sehingga dapat mengoptimalkan aset tetap tanah khususnya terkait pengoptimalkan legal asety tetap tanah.

\section{DAFTAR PUSTAKA}

Antoh, A. E. (2017). Pengaruh Manajemen Aset dalam Optimalisasi Aset Tetap (Tanah dan Bangunan) Pemerintah Daerah (Studi di Kabupaten Paniai). Jurnal Manajemen $\mathcal{E}$ Bisnis, 1(2), 37-47.

Asman, A., Akram, H., \& MT, A. (2016). FaktorFaktor yang Mempengaruhi Optimalisasi Pengelolaan Aset Tetap pada Pemerintah Daerah Kabupaten Sumbawa. Assets, 6(1), 23-38.

Chodariyanti, L. (2019). Efektivitas Sistem Pengelolaan Keuangan dan Aset Daerah. Media Mahardika, 426-435.

Demetouw, M., Salle, A., \& Asnawi, M. (2015). Pengaruh Manajemen Aset terhadap Optimalisasi Aset Tetap Pemerintah Kabupaten Jayapura. Keuda, 2(3), 1-12.

Hartati, S., Martini, R., \& Winarko, H. (2019). Manajemen Aset bagi Optimalisasi Pengelolaan Aset Tetap Kajian pada Pemerintah Kota Palembang. Jurnal Riset Terapan Akuntansi, 3, 40-51.

Jusmin, \& Nursalim. (2018). Pengaruh Manajemen Aset terhadap Tingkat Optimalitas Aset Tetap (Tanah dan
Bangunan) Pemerintah Kota Sorong. Jurnal Equilibrium, 6(Juli), 139-147.

Mahsun. (2003). Analisis Efektifitas Manajemen Aset Properti Riil Pemerintah Daerah, Studi Kasus pada Pemerintah Kota Yogyakarta Tahun 2001/2002. Jurnal Akuntansi dan Keuangan Sektor Publik, 4(02): 1-9

Noviawati, E. (2016). Optimalisasi Pengelolaan Aset Daerah terhadap Penyelenggaraan Otonomi Daerah. Jurnal Ilmiah Galuh Justisi, 4(1), 47-61.

Pauweni, S., Karamoy, H., \& Gamaliel, H. (2017). Pengaruh Inventarisasi, Legal Audit, Penilaian dan Kondisi Aset terhadap Optimalisasi Pemanfaatan Aset pada Pemerintah Daerah Kabupaten Bone Bolango. Jurnal Riset Akuntansi dan Auditing "Goodwill," 8(2), 50-61.

Phelps, A. J. (2009). An Examination of the Relationship between Rationale, Practice and Outcomes in Municipal Property Asset Management - A Comparative Study of the UK and Russia. Dissertation. University of Birmingham. Ph.D.

Pratama, M. R., \& Pangayow, B. J. C. (2016). Pengaruh Manajemen Aset terhadap Optimalisasi Pengelolaan Aset Daerah Studi pada Pemerintah Kota Jayapura. Jurnal Akutansi \& Keuangan Daerah, 11(2), 33-51.

Purba, R. (2019). Pengelolaan Aset Tetap Daerah dalam Mengoptimalkan Pemanfaatan Aset Daerah. Jurnal Akuntansi BIsnis \& Publik, 9(2), 152-164.

Siregar, D. D. (2004). Manajemen Aset Strategi Penataan Konsep Pembangunan Berkelanjutan secara Nasional dalam Konteks Kepala Daerah sebagai CEO's pada Era Globalisasi dan Otonomi Daerah. Jakarta: PT Gramedia Pustaka Utama.

Sriastiti, N. L. P., Ningsih, N. L. A. P., \& Yasa, P. N. S. (2020). The Influence of Asset Management Towards Optimization of State Assets in Working Units in the Denpasar High Court Region. Jurnal Ekonomi \& Bisnis Jagaditha, 7(1), 24-38.

Surminah, L. (2008). Manajemen Aset di Lembaga Litbang. Warta Kebijakan Iptek \& 
Manajemen Litbang. Jakarta: Penerbit Papiptek-LIPI.

Peraturan Menteri Dalam Negeri Nomor 19 Tahun 2016 tentang Pedoman Pengelolaan Barang Milik Daerah.

Peraturan Daerah Kabupaten Malang Nomor 9 Tahun 2018 Tentang Pengelolaan Barang Milik Daerah.
Peraturan Pemerintah Nomor 24 Tahun 2004 tentang Standar Akutansi Pemerintah (SAP).

Wombaibabo, U. (2017). Kontribusi Manajemen Aset terhadap Optimalisasi Aset Tetap Kendararaan Dinas Roda Dua dan Roda Empat di Pemerintah Daerah. Journal Universitas Gadjah Mada, 8(2) 